\title{
Wenhsien Yang*
}

Department of Applied English

National Kaohsiung University of Hospitality and Tourism, Taiwan

yangwenhsien@mail.nkuht.edu.tw

\section{AUDIOSLIDE PRESENTATIONS AS AN APPENDANT GENRE - KEY WORDS, PERSONAL PRONOUNS, STANCE AND ENGAGEMENT}

\section{Abstract}

Due to the competitiveness in academic settings and the convenience of technological platforms, several genres have been designed to promote research. The current research studies audioslide presentations, one of the novel academic appendant genres to promote its host genre, research articles. The corpus includes the spoken transcripts collected from oral presentations in the hard science domains and written by expert scholars. We aimed to identify the structure of the presentations, generate keywords used in the talks with reference to an academic spoken English corpus and a daily English speech corpus, and examine how authorial stance and audience engagement are shown in the presentations by employing personal pronouns. The results demonstrate that the speakers tend to highlight the existence of knowledge gaps and the research designs of the investigations, rather than emphasising the findings. Keywords are also used slightly differently compared to different reference corpora, namely, BNC and BASE. In addition, projecting self-presence is much more prevalent than engaging the audience, and the use of the personal pronouns was found to differ from the assumed knowledge in written texts. This poses the question of whether a promotional text as an appendant genre should be treated as its host genre with an implicit promotional voice.

\section{Key words}

audioslides, appendant academic genre, key words, personal pronouns, authorial stance, reader engagement.

\footnotetext{
* Corresponding address: Wenhsien Yang, 1, Hsung-ho Rd. Hsiao-kang Dist., 812, Taiwan.
} 


\section{Sažetak}

Usled konkurentnosti akademskog okruženja i pogodnosti koje pružaju tehnološke platforme, osmišljeno je nekoliko žanrova kojima se promovišu naučni radovi. U ovom radu istražujemo prezentacije sa audio-slajdovima, jedan od novih akademskih "pripojenih" žanrova uz pomoć kojeg se promoviše njegov žanr "domaćin", naučni rad. Korpus obuhvata transkripte govora autora radova prikupljenih iz usmenih prezentacija u oblasti prirodnih nauka. Cilj nam je bio da identifikujemo strukturu prezentacija, otkrijemo ključne reči i uporedimo ih sa korpusom akademskog govora (BASE) i korpusom svakodnevnog govora (BNC) na engleskom jeziku, te istražimo kako se autorski stav i angažovanje publike ispoljavaju u prezentacijama putem upotrebe ličnih zamenica. Rezultati pokazuju da govornici teže da istaknu postojanje praznina u pogledu znanja i dizajna istraživanja pre nego rezultate istraživanja. Ključne reči se takođe koriste unekoliko drugačije u poređenju sa dva korpusa, BNS i BASE. Pored toga, projektovanje autorskog prisustva izrazitije je u odnosu na angažovanje publike, dok se upotreba ličnih zamenica razlikuje u odnosu na njihovo ustaljeno korišćenje $\mathrm{u}$ pisanim tekstovima. Ovim se postavlja pitanje da li promotivni tekst kao "pripojeni" žanr treba tretirati kao njegov žanr "domaćin" sa implicitnim promotivnim prizvukom.

Ključne reči

audio-slajdovi, "pripojeni” akademski žanr, ključne reči, lične zamenice, autorski stav, angažovanje publike.

\section{INTRODUCTION}

Since academic publication is becoming more obviously competitive in the modern world, promotional features have colonised written and speech events in higher education (Fairclough, 1993; Okamura \& Shaw, 2014). Academic texts are now not only informative as traditionally expected, but are also embedded with evaluative and promotional purposes in order to broaden their visibility and readership. Research papers are written not only to deliver new knowledge, but also to project the author's specific contributions in their academic community. Recently, a number of measures have been deployed to achieve promotional purposes with the help of technological devices, thus generating some novel but appendant genre texts in the academic context (e.g. Elsevier, 2014). For instance, some worldleading international journals have gradually required authors to submit separate bullet-pointed highlights which are published in the on-line version, not only to 
stress the main findings of the research but to arouse potential readers' interest before gaining full access to the paper (Yang, 2016).

In addition to written texts, one of the latest promotion strategies adopted by publishers is to encourage authors to publish webcast-style audioslides ${ }^{1}$ or audio clips $^{2}$ to talk about their research on a designated on-line platform. Differing from formal academic conference presentations, there is no author's presence in these audio presentations, only key words and findings which emphasise the relevance of the research together with powerful imagery providing impact, and professional speakers explaining the content (Sellgate, 2015). Audioslides, integrating both written and spoken acts, give authors opportunities to explain their research in their own words, demonstrate their propositions to convince the audience, and promote their work. Audioslides can help readers quickly understand the subject matter and the relevance of the paper (Elsevier, 2016). They are helpful not only for busy professionals but also for the general public who can "hear that there is a real live person behind what can be some pretty abstract ideas" (Gluckman, 2014). In spite of their growing importance, similar to other novel genres in some leading journals, appendant genres such as audioslides are still less explored by language researchers due to their novelty and implicit status (Yang, 2016). Thus, the present study focuses on how authors attempt to draw attention to their accomplishments by constructing effective audioslides, how keywords are deployed to reach the communicative purposes of the audioslides across disciplinary variations, and how researchers present their authorship and acknowledge the presence of the audience in their audioslides, especially through the use of personal pronouns. This could hopefully shed light on the promotional language expressed in this novel and less studied academic spoken genre. A related goal here is also to help research article authors produce their own effective audioslides.

\section{LITERATURE REVIEW}

Compared with traditional paper presentations, audioslides have some distinguishing features. Firstly, they are relatively brief in duration, less than five minutes. Secondly, they lack face-to-face interaction with the listeners. Thirdly, the content is of high scholarly assurance as it is based on published and peerreviewed research papers. Hence, audioslides are a peculiar genre embedded with academic spoken acts, apparent promotional purposes and professional discourse.

The evaluative and promotional language in research articles (RAs) has been extensively analysed from many different aspects according to a variety of frameworks such as interpersonality, stance, meta-discourse, etc. Making explicit positive evaluation of one's academic achievements is also becoming very common

\footnotetext{
${ }^{1}$ E.g. Elsevier (https://www.elsevier.com/authors/author-services/enrichments/).

${ }^{2}$ E.g. Taylor \& Francis (http://explore.tandfonline.com/page/beh/cccp-strengths-based-practice).
} 
in the competitive world of academia (Shaw, Kuteeva, \& Okamura, 2014). This led to the emergence and heavy use of promotion-oriented 'appendent genres', which are very different from their academic-based host, that is, RAs, in terms of their function and structure.

According to Yang's (2016) classification, two types of genre are found in academic discourse, the host and the appendant genres, depending on their interrelationship. A host genre is a major focus in academic texts, always existing independently. In contrast, an appendant genre can only exist in conjunction with a host and draws less attention, owing to the fact that its space is restricted and that it has a peripheral status (Tse, 2012). The two types of genre have different purposes and exhibit a clear peripheral-nuclear distinction in academic discourse (Shaw, 2016; Yang, 2016). Differing from the host genres, which usually aim to create new knowledge or information, appendant genres are chiefly aimed at sharing information, and are specifically designed to share information relevant to the host genres. They thus often have a much greater promotional purpose. Compared to the investigation on RAs, studies on appendant genres are relatively underrepresented, but they are becoming as prominent as their hosts. "Increasingly appendant genres are viewed as indispensable in academic contexts as they perform a higher promotional function to highlight their hosts in the competitive world of academia" (Yang, 2016: 91). These appendant genres such as book blurbs, bio-statements, journal descriptions, highlights and audioslides are thus expected to shoulder the main duties of promoting their host genres, that is, research papers or proposals (Yang, 2016). It is assumed that more innovative appendant genre texts would appear to support their host genres as the rapid development of technology provides an ideal platform for rapidly disseminating those evaluative and promotional messages to the world, surmounting the constraints of time and location (Schwanen \& Kwan, 2008).

As noted by Yang (2016) previously, one common strategy used by authors to achieve their promotional and persuasive purposes in academic discourse is to employ certain linguistic devices to represent their stance and engagement with readers, and in so doing connect with them (Hyland, 2005a). As Hyland (2005a) proposes in his stance (a textual voice or community recognised personality following others) and engagement (the writer's relation to readers with respect to the positions advanced in the text) model of studying RAs, these disciplinarysensitive linguistic devices, including hedges, boosters, attitude markers, selfmention, reader pronouns, directives, questions, shared knowledge, and personal asides, are used to express the authors' voices, represent their positions and themselves, and acknowledge their readers' presence (Hyland, 2008a). Projecting authorial stance not only contributes to the interaction between authors and readers, but is also viewed as a way to persuade the audience and promote the researchers' work. Also, studies have underlined not only cross-cultural (Breivega, Dahl, \& Fløttum, 2002; Hu \& Cao, 2011; Mauranen, 1993; Mur-Dueñas, 2007) but also cross-disciplinary (McGrath \& Kuteeva, 2012; North, 2005) differences in the 
use of linguistic devices in academic rhetoric. Research on how writers present their positions, evaluate arguments, relate to readers and then convince them of propositions in their texts has demonstrated that choices in rhetorical devices and the conventions of using voice and tense in reporting procedures and results as well as in making arguments in different sections of academic texts (Yang, 2015) vary from discipline to discipline (e.g. Hyland, 2001, 2005a, 2005b, 2008b).

In contrast to the relatively conventional features of the above language uses, the tendency to use specific or various lexis highlights more clearly the disciplinary variations in academic discourse. One category of these words, that is, keywords, is believed to be important in helping differentiate the textual features. Keywords are words which show a high frequency of occurrence compared to a reference corpus (Bondi \& Scott, 2010; Scott, 2014; Scott \& Tribble, 2006). Keyword analysis, as a form of qualitative analysis, can help identify the significance of lexis in a given set of academic texts (Groom, 2009) and is beneficial in terms of establishing "a clear understanding of colligational and collocational relationships which generically significant words take on in the discourse" (Tribble, 2013: 137). Analysing keywords has increasingly become of interest in the study of the evaluative features of discourse, and in sketching the lexico-grammatical resources of the texts studied (Martin \& White, 2005). Keywords not only indicate the significance and importance of lexis to the texts described (Tribble, 2013), but also often provide "a way of identifying which words best distinguish the texts of a particular author or group of authors from another" (Hyland, 2012: 68). In addition, they are closely associated with the disciplinary cultures, assumptions, and value systems in academic discourse (Groom, 2009). Research on keywords is extensive across various genre types (see Scott, 2014), with a number of studies comparing their use in the soft and hard science domains and demonstrating that differences do in fact exist (e.g. Yang, 2012, 2013, 2014).

However, studies on how speakers represent their stance and relate themselves to their audience by employing certain keywords in the appendant genres, in particular spoken texts, are relatively underrepresented, probably owing to their novelty and marginal status. Yet, the present study argues that promotional culture is quickly intruding into academic written and spoken events, and that the responsibility of promoting academic work no longer lies solely with the publishers, but that authors and researchers are gradually being expected to share the duty of promotion. What researchers have to do now is not only prepare their papers and have them accepted for publication, but also attract more potential readers, gain higher visibility in the academic community, and potentially increase the number of citations to achieve maximum impact (Elsevier, 2014). In other words, researchers are currently being forced to familiarise themselves with these novel appendant genre texts to produce evaluative, interactive, and persuasive texts. Thus, the present study attempts to analyse how one of these genres, audioslides, works as a new academic spoken genre in the hard science domain where authorial-mentions are scarcely used as a convention in academic 
texts to promote research and interact with the audience through the analysis of personal pronous and keywords. It is hoped that this investigation can bridge the gap in researching academic appendant genres in the literature.

To be specific, the present research aims to answer the following questions:

1. What is the general structure and information included in an audioslide presentation?

2. What are the keywords employed in audioslides of the hard sciences which differentiate them from other academic texts?

3. What interactive discourse in terms of self-mentions and reader pronouns are deployed to represent authorial stance and readers' engagement in the audioslides of the hard sciences?

\section{METHODOLOGY}

In this section, we describe how the samples of the audioslides were collected from the hard sciences to create the corpus for the present study. Also, the two reference corpora and the analysis instrument used for generating keywords are discussed.

\subsection{Corpus}

All of the audioslides in the present study were collected from a world-leading journal publisher, namely Elsevier, and were taken from the hard sciences. In addition, all of these audioslides are appendant to full papers appearing in SCIindexed journals. The audioslides mainly include the engineering and technology disciplines across different journals such as Engineering Structures, the Journal of Constructional Steel Research or Mechanism and Machine Theory ${ }^{3}$. In a competition held by the publisher, only the authors of the most downloaded papers in the engineering and technology journals were invited to produce audioslides (Elsevier, 2013). In total, 67 audioslide sets were created and published on-line for free viewing by the public. In late 2013, the winners of this competition were announced and, interestingly, the three winning presentations based on a mostviewed list were all produced by non-native English authors and speakers, namely Hong Kong Chinese, French/German and Italian. The total number of slides in the 67 audioslide sets was 297, of which 97 were text only, 78 contained only graphic illustrations such as figures, tables, graphs, etc., and the other 122 were composed of both text and graphics.

\footnotetext{
${ }^{3} \mathrm{~A}$ full video of all of the audioslide presentations can be accessed via https://www.youtube.com/ channel/UCNaZuYnm5YcwbUPtvfCVrxA/videos.
} 
The collected audioslides were then watched and transcribed. However, due to the different disciplinary backgrounds of the researcher and research assistants, and the research focus on the keywords, evaluative language and interactive discourse in the present study, the audioslides were not transcribed on a word-byword basis but instead only the language which was deployed to represent stance and engagement in the research was transcribed. In other words, disciplinary terminology and specific disciplinary knowledge, where the symbol $X$ was inserted, were not included in the follow-up analysis (see examples of transcription below [1-3]).

(1) Over the next five minutes I will present a standard [project] by Daniel and myself as part of an EU-funded $X$ called $X$. Our study is about helping in easily recognizable geographic information system-based methodology for assessing the costs a sea level rise in extreme coastal flooding at the local level.

(2) L1 is the bond length and L2 is longer than L1 so that the specimen will fail on the L1 side on the $X$ are loading. In order to control the adhesive $X$, a special device in figure 3 was designed to make sure all the specimens have identical bone length thickness.

(3) Interestingly, the shape of the $X$ around is mostly estimated, making $\operatorname{MT}(X)$ a good feature extractor of motion contrasts. Our goal is $X$ how a richer $X$ percent $X$ given by the diversity. Sometimes $X$ configuration could provide $X$ for high-level task such as actual recondition.

The transcribing task was done by the researcher and his research assistants and was verified for accuracy by one Taiwanese English-speaking colleague.

\subsection{Instruments and analysis}

First of all, to answer research questions 1 and 2, the transcription was imported to the concordancing tool, WordSmith Tools (Scott, 2008). The present major corpus was used as the study corpus, while BNC (British National Corpus) and BASE (British Academic Spoken English) were used as the reference corpora to generate the keywords employed by the speakers and to make a possible comparison between the two corpora. Keywords refer to that lexis which occurs significantly frequently or rarely, compared to the reference corpus, and analysing them can help researchers avoid trivial and insignificant words, and focus instead on what lexis distinguishes the studied texts from other text types (Scott \& Tribble, 2006). Keywords contain keyness and aboutness of lexis, showing their particularities in a specific given text (Culpeper, 2009; Tribble, 2013).

Apart from transcribing the audioslides, an observation form was also designed to attend to the semiotic and structural features of the audioslides. The transcribers had to note down what each slide addresses in relation to the research articles (e.g. Introduction, Literature review, Methodology, Results, or 
Discussion), and the components of each slide (e.g. words only, graphics only, or a mixture). Each audioslide is a very condensed version of a full paper, so only deliberately selected sections are reported in them. This analysis helps to identify which sections of a full paper would be regarded as the most significant by the speaker, and thus why s/he decided to highlight these points to promote the research. Besides, we took a closer look at what keywords demonstrate how the speakers intentionally designed the slides to grab potential readers' attention, to strategically direct them to the relevance of the research, and to successfully ignite their interest in accessing the full paper with a rather short talk and show. The reference corpora used to generate keywords of the present corpus, BASE and BNC, respectively show the relation to academic and ordinary English.

Then, to answer research question 3 , to examine the features of interactive language, Hyland's (2005a) model of stance and engagement was adopted with special attention paid to the use of personal pronouns. The wordlist of the corpus generated by WordSmith Tools was used to locate these linguistic devices, and manual coding was applied again. The concordance function of WordSmith was operated to help locate the entries of using the personal pronouns in the corpus.

\section{RESULTS AND DISCUSSION}

\subsection{The structure and information included in audioslide presentations}

Table 1 shows the distributions of the slides, representing the IMRD sections individually in each research article. As can be seen, slides containing both words and graphics are the most common design as they help not only convey the core message but summarise the major findings and thus attract the audience's attention. The introduction, method and results sections are the top three sections the presenters addressed. In the hard disciplines, most of the presenters tended to talk more about their motivation for conducting the research due to the lack of previous studies, then proposed novel methods to verify their hypotheses, and provided those of their findings which were confirmed to be significant. A lack of reviewing the relevant literature is natural due to the limited time and purpose of audioslides.

\begin{tabular}{|c|c|c|c|c|c|c|}
\hline WORDS & NON-WORD & BOTH & INTRO. & METHOD & RESULTS & DISCUSSION \\
\hline $\mathbf{9 7}$ & 78 & 122 & 102 & 88 & 84 & 49 \\
\hline $\mathbf{3 2 . 7 \%}$ & $26.3 \%$ & $41.1 \%$ & $31.6 \%$ & $27.2 \%$ & $26.0 \%$ & $15.2 \%$ \\
\hline
\end{tabular}

Table 1. Layout of the slides and number of slides in each section 
However, it is interesting that the presenters did not highlight their findings completely in accordance with the guidelines of designing audioslides offered by the publisher. This is similar to writing 'highlights' in research articles, where researchers may have different interpretations of the actual effects of these promotional appendant genres from the publishers' expectations (Yang, 2016). In academia, 'Publish or Perish' is researchers' top priority, but 'Publish and Promote' could be publishers' major concern.

\subsection{Keywords employed in the audioslides vs. BASE}

Table 2 displays the top 20 over- and under-used keywords in the corpus of audioslides compared to BASE, which indicates its disciplinary peculiarities or differences from a general academic domain. Keywords contain significantly overused and underused (in italics) lexis, compared to the study corpus. The topranking overused keywords, model, descriptors, method, are in line with the previous discussion that hard scientists are inclined to introduce a new model or method in their research design in order to distinguish their research from others. Optimisation demonstrates a common practice in hard science of evidencing a better method, while tsunami represents the current research needs or academic interest, connected to the huge earthquake in Japan in 2011. The underused keywords, were, quite, much, and might, also explain some conventions of the hard sciences. Past tense, hedges or adverbials are less frequently used in order to present certainty of knowledge.

\begin{tabular}{|c|c|c|c|c|}
\hline $\mathbf{N}$ & KEY WORD & FREQ. & RC. FREQ. & KEYNESS \\
\hline $\mathbf{5}$ & SLIDE & 162 & 149 & 882.8343506 \\
\hline $\mathbf{9}$ & TITLE & 67 & 110 & 309.9085083 \\
\hline $\mathbf{1 2}$ & OPTIMIZATION & 33 & 2 & 251.073288 \\
\hline $\mathbf{1 4}$ & BEHAVIOR & 28 & 0 & 225.9760437 \\
\hline $\mathbf{1 5}$ & MODELING & 27 & 0 & 217.9046021 \\
\hline $\mathbf{1 6}$ & MODEL & 79 & 462 & 204.3112946 \\
\hline $\mathbf{1 7}$ & DESCRIPTORS & 26 & 1 & 201.3146973 \\
\hline $\mathbf{1 8}$ & PMIS & 24 & 0 & 193.6906433 \\
\hline $\mathbf{1 9}$ & RESULTS & 51 & 151 & 188.7428741 \\
\hline $\mathbf{2 0}$ & MOTION & 39 & 56 & 188.1231995 \\
\hline $\mathbf{2 1}$ & FLOW & 54 & 186 & 186.5655518 \\
\hline $\mathbf{2 2}$ & PAPER & 57 & 220 & 186.3130798 \\
\hline $\mathbf{2 3}$ & CUTTING & 37 & 47 & 185.0421906 \\
\hline $\mathbf{2 5}$ & CENTER & 21 & 0 & 169.4772644 \\
\hline $\mathbf{2 6}$ & METHOD & 48 & 164 & 166.4624481 \\
\hline $\mathbf{2 7}$ & THE & 2210 & 92880 & 163.6557312 \\
\hline $\mathbf{2 8}$ & FIGURE & 51 & 206 & 162.884491 \\
\hline $\mathbf{2 9}$ & PEENED & 19 & 0 & 153.3353424 \\
\hline $\mathbf{3 0}$ & TSUNAMI & 19 & 0 & 153.3353424 \\
\hline
\end{tabular}




\begin{tabular}{|l|c|c|c|c|}
\hline $\mathbf{4 1 2}$ & WERE & 29 & 3591 & -24.5092144 \\
\hline $\mathbf{4 1 3}$ & READING & 6 & 1536 & -24.69351387 \\
\hline $\mathbf{4 1 4}$ & QUITE & 11 & 2085 & -25.77120972 \\
\hline $\mathbf{4 1 5}$ & MUCH & 12 & 2261 & -27.77534485 \\
\hline $\mathbf{4 1 6}$ & SAID & 6 & 1649 & -27.879673 \\
\hline $\mathbf{4 1 7}$ & LOT & 3 & 1317 & -28.71796417 \\
\hline $\mathbf{4 1 8}$ & DOWN & 5 & 1570 & -28.89549065 \\
\hline $\mathbf{4 1 9}$ & THEIR & 19 & 2988 & -29.69481277 \\
\hline $\mathbf{4 2 0}$ & BE & 133 & 11506 & -30.17448807 \\
\hline $\mathbf{4 2 1}$ & THEN & 44 & 5202 & -32.46446228 \\
\hline $\mathbf{4 2 2}$ & COURSE & 7 & 1974 & -33.96237564 \\
\hline $\mathbf{4 2 3}$ & ALL & 56 & 6241 & -34.35237503 \\
\hline $\mathbf{4 2 4}$ & AT & 94 & 9087 & -34.68251038 \\
\hline $\mathbf{4 2 5}$ & OUT & 19 & 3251 & -35.89786148 \\
\hline $\mathbf{4 2 6}$ & YOUR & 21 & 3514 & -37.78465271 \\
\hline $\mathbf{4 2 7}$ & ONE & 77 & 8045 & -37.99086761 \\
\hline $\mathbf{4 2 8}$ & THOSE & 9 & 2345 & -38.19983292 \\
\hline $\mathbf{4 2 9}$ & NO & 15 & 2973 & -38.45730972 \\
\hline $\mathbf{4 3 0}$ & MIGHT & 4 & 1774 & -38.85839081 \\
\hline $\mathbf{4 3 1}$ & KIND & 5 & 1964 & -40.73535156 \\
\hline
\end{tabular}

Table 2. Top 20 over- and under-used keywords of the audioslides vs. BASE

\subsection{Keywords employed in the audioslides vs. BNC}

Differing from the previous section, Table 3 exhibits the top 20 keywords compared to another reference corpus, BNC, which generates more disciplinespecific keywords. One exception is the overuse of we. Due to the collaborative environment of involving multiple authors in hard science research, the word is vastly deployed to express authorial stance across the talk in the audioslides. In addition, this also implies that, to stress the value of one's research, the use of the first person plural pronoun seems necessary. Hence, it is not surprising to see the words $I$ and $m e$ as underused lexis in the list. Another interesting finding is that some overused keywords such as optimisation, modelling, and behaviour were yielded in both corpora. These occurrences confirm the significant keyness and aboutness of the lexis in technology and engineering field, compared to other disciplines and discoursal communities.

However, interestingly, the common words $a$ and it are also underused in the corpus. It is assumed that in hard knowledge, specifying the object is more common than using the indicative pronoun, and also repeating the object may be necessary to impress the audience since, unlike when reading articles, listeners have few chances to look back at what the pronoun indicates in a talk. Therefore, explicit indication of objects throughout the presentation can be a strategy for delivering a successful audioslide talk. 


\begin{tabular}{|c|c|c|c|c|}
\hline $\mathbf{N}$ & KEY WORD & FREQ. & RC. FREQ. & KEYNESS \\
\hline 2 & SLIDE & 162 & 1733 & 1518.438354 \\
\hline 8 & OPTIMIZATION & 33 & 46 & 427.030304 \\
\hline 9 & MODELING & 27 & 11 & 391.4859619 \\
\hline 12 & BEHAVIOR & 28 & 88 & 325.236084 \\
\hline 13 & WE & 302 & 285843 & 322.3642273 \\
\hline 14 & MODEL & 79 & 13104 & 321.289978 \\
\hline 16 & PEENED & 19 & 0 & 307.6591187 \\
\hline 17 & DESCRIPTORS & 26 & 91 & 297.1174011 \\
\hline 18 & TITLE & 67 & 9863 & 287.6466064 \\
\hline 19 & FLOW & 54 & 5363 & 272.5678711 \\
\hline 25 & CENSORING & 17 & 22 & 221.8635406 \\
\hline 26 & MACHINING & 19 & 71 & 214.9258575 \\
\hline 28 & SOLUTION & 47 & 6713 & 204.4573364 \\
\hline 30 & ALGORITHM & 24 & 550 & 189.5991669 \\
\hline 31 & METHOD & 48 & 8886 & 185.2209167 \\
\hline 32 & MOTION & 39 & 4589 & 184.1072845 \\
\hline 34 & VIBRATION & 22 & 462 & 177.5301208 \\
\hline 35 & CUTTING & 37 & 4212 & 177.0148315 \\
\hline 36 & USING & 67 & 24448 & 175.1508331 \\
\hline 37 & USABILITY & 15 & 52 & 171.6605225 \\
\hline 407 & OVER & 14 & 134980 & -24.1293335 \\
\hline 408 & $B E$ & 133 & 654605 & -25.32626724 \\
\hline 409 & STILL & 3 & 71788 & -25.85355186 \\
\hline 410 & $O F F$ & 3 & 73692 & -26.85794067 \\
\hline 411 & THINK & 5 & 88270 & -26.99907875 \\
\hline 412 & $I$ & 134 & 673709 & -28.48208809 \\
\hline 413 & DO & 19 & 173466 & -28.89756775 \\
\hline 414 & JUST & 10 & 124169 & -29.10366631 \\
\hline 415 & DOWN & 5 & 93460 & -29.59404755 \\
\hline 416 & OR & 60 & 371791 & -30.44300842 \\
\hline 417 & YEARS & 4 & 88394 & -30.64540863 \\
\hline 418 & $B E E N$ & 35 & 259712 & -31.26456833 \\
\hline 419 & WHAT & 25 & 212348 & -31.94386292 \\
\hline 420 & $A T$ & 94 & 525833 & -32.39422607 \\
\hline 421 & THEM & 15 & 166258 & -34.87642288 \\
\hline 422 & OUT & 19 & 201528 & -40.32853317 \\
\hline 423 & THERE & 32 & 279200 & -43.70470428 \\
\hline 424 & $M E$ & 6 & 130320 & -44.80247116 \\
\hline 425 & $A$ & 496 & 2172878 & -46.74647522 \\
\hline 426 & $I T$ & 169 & 905189 & -48.54029083 \\
\hline
\end{tabular}

Table 3. Top 20 over- and under-used keywords of the hard science audioslides vs. BNC 


\subsection{The use of $I$ in the audioslides}

In the following sections, we discuss how researchers in the hard sciences present themselves in the audioslides presentations by deploying the first person pronouns. In some appendant genres like the current one, hard science researchers are happier than soft science scholars to use the first person pronouns (Okamura \& Shaw, 2014; Yang, 2016), which is, however, apparently different from Hyland's (2005a) argument that soft discipline authors tend to project their roles in research, while hard science writers tend to minimise their presence in RAs. This difference evidences that audioslides, as one appendant genre, have a slightly different communicative purpose, compared to its host genre, RAs and therefore, different rhetorical conventions are used to meet those purposes. Some examples were selected for discussion below.

Table 4 shows some features of its use in the hard sciences and Appendix tabulates the frequency and common collocations of all the personal pronouns. Firstly, the tenses can be varied. Not only do present and past tense follow $I$, but future tense, which is relatively less seen in RAs, is also possible in these slides. Secondly, the presenters used the pronoun across various sections of their papers (IMRD) to claim authorship. They emphasised their presence in the research design and analysis procedure to specifically highlight the unique novelty and absolute significance of their investigations. In line with the conference presentations (CP), presenters in the audioslides also used the first person pronouns, followed by an active verb to "express actions and opinions congruently and take personal responsibility for their decisions and interpretations" (CarterThomas \& Rowley-Jolivet, 2003: 4). Due to the environment in which much information has to be delivered within the constraints of time, using the first person pronouns in the audioslides can help speakers express their opinions and comments more openly and directly (Rowley-Jolivet \& Carter-Thomas, 2005).

Besides, in spite of the fact that all papers in the corpus were multiple authored, some presenters chose $I$ and we interchangeably to represent multiple authorship in the presentations. One possible explanation is that the single speaker decided to take full responsibility for mistakes or errors raised in the presentation. This device is very similar to a common statement in the dissertation/thesis acknowledgements, 'All errors in the dissertation belong to me solely', where the author tries to protect his/her supervisors or committee members. Likewise, here the presenter would perhaps like to protect the rest of the senior authors in their research and decided to solely take the full responsibility for making this presentation. 


\begin{tabular}{|c|c|}
\hline $\mathbf{N}$ & CONCORDANCE \\
\hline 1 & ...this study that presentation. $I$ am $X$ the world to discuss a ... \\
\hline 2 & $\ldots$ an, for the next five minutes, $I$ am going to tell you about ... \\
\hline 3 & Hello, I am xx from xx xx Italy. In ... \\
\hline 4 & My name is doctor Chhaniyara. I am a research fellow. At ... \\
\hline 5 & ... are used in the trade of study $I$ explained here the table ... \\
\hline 6 & In that applicability for subsurface as I detect and do what improving ... \\
\hline 7 & ...in Jerusalem. Over the next five minutes $\boldsymbol{I}$ will present a standard teammate by ... \\
\hline 8 & In three main stages and $\boldsymbol{I}$ will describe each stage in detail in ... \\
\hline 9 & ...mechanical properties issuing the X. I ensure analysis on X $200 \mathrm{X}$ meter high ... \\
\hline 10 & l ground gradient orientation appearance $\boldsymbol{I}$ 've used to calculate the of this 3D... \\
\hline 11 & ...to responding the image plans $I$ 've shown in figure 2 . In each of the ... \\
\hline 12 & Welcome to this audio slides session. I am not the one of the author of ... \\
\hline 13 & ...one of the author of dissertation paper. $I$ try to analysis the key point of the ... \\
\hline 14 & ...shown in the right figure. At the end $I$ would like to emphasis on the major ... \\
\hline 15 & During this presentation $I$ will be giving the description of our ... \\
\hline
\end{tabular}

Table 4. Examples of the use of $I$ in the audioslides

\subsection{The use of $W e$ in the audioslides}

$W e$ is more frequently used than $I$ to represent self in the slides, and it is mainly deployed as an exclusive we and as an authorial marker (e.g. we aim to, we would suggest, we propose, etc.) where it only refers to the authors, but sometimes engages listeners as an inclusive we (e.g. we can see [10], as what we can expect [8], we have witnessed [16], and we must know [14]), as exemplified in Table 5. Similar to CP (Rowley-Jolivet \& Carter-Thomas, 2005), in the audioslide presentations, the inclusive we signals disciplinary solidarity by engaging the audience in the research choices and decisions, while the exclusive we mainly recounts the actions taken by the team-mates to do research.

Different from using $I$ to claim sole responsibility or absolute authorship, exclusive $w e$ is the less obvious marker of authority for sharing responsibility and expressing ambiguity (Okamura \& Shaw, 2014); besides, it can downplay personal intrusion and yet still stress a unique procedure or important view (Hyland, 2001). In the audioslides distribution of its appearance referring to the different sections in its RA, we in the hard sciences of the slides equally appears in each section of a paper to introduce the topic, to describe the instruments, to discuss the results and to reach the conclusion. In other words, we in hard science presentations is not only limited to addressing methodology or action as it was in Mur-Dueñas' (2007) study. Thus, it seems clear that the use of these pronouns is different because the genres serve different communicative purposes and use two different modes. 


\begin{tabular}{|c|c|}
\hline $\mathbf{N}$ & CONCORDANCE \\
\hline 1 & ...ponding optimization procedure. We demonstrate that combining ... \\
\hline 2 & ...of the unknown high resolution $\mathrm{Y}$ and $\mathrm{X}$ we aim to recover. Our image generation ... \\
\hline 3 & ...condition only for $\mathrm{x}$ and basic solutions. We wanted the functions to decreasing a ... \\
\hline 4 & ...optimization problem must be fuzzy. We would suggest to reflect this uncertainty ... \\
\hline 5 & ...performance then understaffed the game $\boldsymbol{w} \boldsymbol{e}^{\prime} \mathrm{d}$ like to develop into an adjustment... \\
\hline 6 & ...is challenging. Let's see what we can do. Many types of simulations can ... \\
\hline 7 & ...network architectures. For this result, we propose the simulation framework ... \\
\hline 8 & ....assimilated XX more than X get note. As we could expect, XX introduce X information ... \\
\hline 9 & ... and information major, for example, we repeatedly generate parameters from ... \\
\hline 10 & ... on a proposed results and what we can see quite clearly the very bottom ... \\
\hline 11 & ...in comparison to all the methods. Here, we compare our proposed approach again ... \\
\hline 12 & ... but also applicable more generally where we seek to create features which built ... \\
\hline 13 & ...studied for quite years even decades. $\boldsymbol{W e}$ believe that we have effective ... \\
\hline 14 & ...effects in the X Voltage. Secondly, we must know the X current Is before the ... \\
\hline 15 & Thank you very much for your time we hope you have fun in this introduction... \\
\hline
\end{tabular}

Table 5. Examples of the use of $W e$ in the audioslides

\subsection{The use of Our in the audioslides}

Table 6 demonstrates the deployment of the first person plural possessive adjective or determiner, our. The singular possessive my is also found in the corpora but with relatively fewer appearances and with unified usage (e.g. my name is or my presentation) and thus is not discussed. In the hard science talks, our is often followed by the research design, aims and proposals to signify the uniqueness of the investigation. They used our to lead a claim or aim because apparently this authoritative voice is relatively common in the hard disciplines, where research findings are expected to be full of individual innovations or peculiarities, and also knowledge is contributed by group authorship in this appendant genre. However, other than the differentiation of inclusive and exclusive we, interestingly our in the present corpus apparently only refers to group authorship, that is, it is the exclusive our. Speakers used our to highlight the solely possessive contribution or intellectual property of the research team to distinguish their study from previous ones. This usage could be one feature of promoting research in the genre under study.

\begin{tabular}{c|l|}
\multicolumn{1}{|c|}{ N } & \multicolumn{1}{c|}{ CONCORDANCE } \\
\hline 1 & $\ldots$ duration time. This is because with our approach higher frequencies in case ... \\
\hline 2 & ...corresponding membership functions x. So our task is to find and element of a ... \\
\hline 3 & ..objective function and crisp constraints. Our position is that the solution of the... \\
\hline 4 & Thank you for your interest in our work. \\
\hline 5 & ...boundary conditions meaning that our solutions are general and we can as... \\
\hline
\end{tabular}




\begin{tabular}{|c|l|}
\hline 6 & ...flood elevations we never see to create our flood zones for each scenario using... \\
\hline 7 & ...rather complicated flow chart describes our method. With different flood ... \\
\hline 8 & ...scenarios we hope you will enjoy reading our paper and visiting our sites. Paper... \\
\hline 9 & ...needs for bicycle and exercise bike. Our survey show that users wanted to... \\
\hline 10 & ...is explaining theoretical background of our research model. As you can see... \\
\hline 11 & ...overreached on the boat sinks. Firstly, our show results using teenagers admitted... \\
\hline 12 & As we can see from the table that, our technique gives better X than other... \\
\hline 13 & ...used shape descriptors. We compare our proposed descriptors against these... \\
\hline 14 & The order to understand these fails our goal is to design a miraculous frame... \\
\hline 15 & ...algorithm, simu-algorithm, and MBO. In our premium studies, the best amount... \\
\hline
\end{tabular}

Table 6. Examples of the use of Our in the hard science audioslides

\subsection{The use of $U s$ in the audioslides}

Compared to the previous deployments of projecting self, the usage of us is relatively less frequent, as Table 7 exhibits. Similarly, it includes both exclusive us to present themselves and inclusive $u s$ to acknowledge and engage the presence of the audience in the talk (Hyland, 2005a). However, differing from our, for which exclusive usages were not found, the inclusive $u s$, in contrast, takes up an equal number of entries in the corpus. The speakers use us to include both researchers and the audience to think about the current problem (e.g. N1, N3) and to carry out the solutions in the future (e.g. N2, N4), that is, inviting the readers to identify the gap and engage in the application of the research. This strategy helps build a sense of solidarity between speakers and listeners to ensure the conducted research is for collective benefit, not for individual interest only. That is, us can sometimes be used by speakers to invite the audience's involvement in research, as can we.

\begin{tabular}{|c|c|}
\hline $\mathbf{N}$ & CONCORDANCE \\
\hline 1 & ...numbers of membership function that $\mathrm{x}$. Let $\boldsymbol{u s}$ consider a fuzzy objective function... \\
\hline 2 & ...current is $\mathrm{X}$ chart and it give $\boldsymbol{u s} \mathrm{X}$ it has physical meaning. This is... \\
\hline 3 & ...to describe flows at smaller scales made us question the truth of the ideas... \\
\hline 4 & ....at the same time is technology allow $u$ s to see and better understand the... \\
\hline 5 & ...and percentage difference are define $\boldsymbol{u s}$ showing $\mathrm{x}$ line. Figure 1 shows the... \\
\hline 6 & ...then this paper. This work can pick us finding the mechanical structure... \\
\hline 7 & ...details. You are also welcome to email $\boldsymbol{u s}$ for any questions.... \\
\hline 8 & ...to define this feature. So let $\boldsymbol{u s}$ look at 3 ideas of visual system.... \\
\hline 9 & ...need to develop an interface that allows $\boldsymbol{u s}$ to collect and process date... \\
\hline 10 & ... X compatible to the $\mathrm{X}$ they made for $\boldsymbol{u s}$ at the side. If you do not consider... \\
\hline
\end{tabular}

Table 7. Examples of the use of $U s$ in the hard science audioslides 


\subsection{The use of You in the audioslides}

Sections 4.8 to 4.10 discuss the ways in which the audience is indicated in the talks, mostly using the second person pronouns, you and your. Table 8 displays the employment of you in the hard science audioslides. As argued by Hyland (2005a), engagement devices tend to be implicitly embedded in texts, and reader pronouns are the most explicit way of including the audience in the discourse. In promotional academic appendant genres, readers or listeners are the target audience the text (either spoken or written) is designed for. The main purpose of promotional genres should lie in raising the receivers' attention and engagement; yet, researchers relatively less explore the communicative purpose, i.e. promotions in the appendant texts, which may lead them to overlook the importance of involving their audience (Yang, 2016) except for the use of inclusive pronouns as discussed previously.

In the present corpus, many of the uses of you are merely to express the speakers' gratitude and wishes for the listeners' watching, or in the phrase, 'as you can see', which draws a clear line between the speakers and the audience. Few examples allow the audience to project themselves as doing research as the authors have done (e.g. if you observed, you can get, and you need to). This usage connects the audience with the presenters and treats them equally as potential or expert researchers.

\begin{tabular}{|c|c|}
\hline $\mathbf{N}$ & CONCORDANCE \\
\hline 1 & ...them as so-called optimization problems. You know a paper we investigate fuzzy ... \\
\hline 2 & ...needed $\mathrm{x}$ the operations $\mathrm{x} 70$ this in day you need to be at on in a timely manner... \\
\hline 3 & .... topic for a future research. Thank you for your attentions. \\
\hline 4 & ...thank you for your interesting, and invite you to enjoy the article... \\
\hline 5 & ...the next five minutes, I am going to tell you about the Inference for the Weibull... \\
\hline 6 & .... trade-off analysis methodology for you really do this techniques. This art... \\
\hline 7 & Different lighting scenarios we hope you will enjoy reading our paper and... \\
\hline 8 & ...manic on screen, it turns out that you can get away with down sampling... \\
\hline 9 & ...this is not statistically significant. You know we show some results this is a... \\
\hline 10 & ...of professional $\mathrm{xxx}$ is on $\mathrm{x}$ table. If $\mathrm{you}$ observed that $\mathrm{xx}$ location is... \\
\hline 11 & ...which respected for everything. As you can see, in all of the real problem... \\
\hline 12 & ...using finite element simulations. Should you have any questions or comments on... \\
\hline 13 & ...caught by the centre. Most of the cases you need to remember. Different types... \\
\hline 14 & ...enjoyed this presentation and we recommend you to read the paper for more details. \\
\hline 15 & ...to refer to a paper for further details. You are also welcome to email us for an... \\
\hline
\end{tabular}

Table 8. Examples of the use of You in the audioslides

\subsection{The use of Your in the audioslides}

The function of using the possessive second person determiner your is the same as that of you (see Table 9), that is, the audience's watching is appreciated. Another 
way of using it is to include the listeners in the research, making them part of the research and conveying a sense of engagement. Apparently, like the speakers in conference presentations (Carter-Thomas \& Rowley-Jolivet, 2003; Rowley-Jolivet \& Carter-Thomas, 2005), the researchers in the hard disciplines engage their audience much more boldly in the audioslides than in the RAs. The reasons why they use the second person pronouns to address their audience may result from the fact that both conference and audioslide presenters clearly know that there must be listeners or an audience sitting in front of them, no matter whether they are physically present or not, and thus establishing a rapport or interaction in a friendly tone seems natural.

\begin{tabular}{|c|l|}
\hline $\mathbf{N}$ & \multicolumn{1}{c|}{ CONCORDANCE } \\
\hline $\mathbf{1}$ & ...for a future research. Thank you for your attention. \\
\hline $\mathbf{2}$ & ...to traffic comedian analysis for plan to your words. A review of key in city... \\
\hline $\mathbf{3}$ & ...or more details. Thank you very much for your time we hope you have fun in this... \\
\hline $\mathbf{4}$ & ...look at this reason the first row in your combination out of the previous... \\
\hline $\mathbf{5}$ & ...the use of coloured wax crayon marks into your face of Dexter additional. In this... \\
\hline $\mathbf{6}$ & ...proposed X motion-based features correct your recognition. The contribution that... \\
\hline $\mathbf{7}$ & ...in one action. Well, for one bearing to your being inspected for three times at... \\
\hline $\mathbf{8}$ & ....ontinue based approach. Thank you for your attention to the presentation. \\
\hline $\mathbf{9}$ & ...model is able to accommodate inclusion your inside insane dosimetric singly... \\
\hline $\mathbf{1 0}$ & ...first author doctor Chao Wu. Thanks for your attention. \\
\hline
\end{tabular}

Table 9. Examples of the use of Your in the hard science audioslides

\subsection{The use of Reader in the audioslides}

The last lexical item used to represent the audience is reader, with only one occurrence as exhibited in Table 10. Although the lexical items listeners and audience have a similar function to readers, they were not found at all in the present corpora. Reader is relatively neutral compared to personal pronouns, and this usage only appears once. In the conventions of writing hard discipline research, maintaining a neutral tone to keep the research replicable and duplications unaffected by human factors can be highly important. Thus, in the RA minimising self-presence is a required conventional research practice in the hard knowledge domain, not to mention projecting the readers or listeners. On the other hand, human beings often play a vital role in soft disciplines; the neutral indicator of the audience, readers, is thus not commonly used.

\begin{tabular}{|c|c|}
$\mathbf{N}$ & CONCORDANCE \\
\hline 1 & ...the crack types are presented. Interested reader can refer to our paper for the... \\
\hline
\end{tabular}

Table 10. Example of the use of Reader in the hard science audioslides 


\section{CONCLUSION}

This paper examined a novel but less-attended genre in academic publication, namely audioslides. Authors of journal papers create a 5-minute on-line presentation, talking about and promoting their research to attract the audience's attention. Audioslides from the hard sciences were collected as the study corpus for identifying their structure, generating the keywords and observing the word use for representing authorial stance and engaging with the audience through the use of personal pronouns. The results indicate that, first, the speakers tended to mainly address the motivation and methods of their research in their talks, instead of spending time summarising and highlighting the findings. This inclination is apparently contradictory to the main purpose of creating audioslides as claimed by the publishers (Elsevier, 2016). Secondly, the keyword analysis shows that the hard discipline researchers had many both overused and underused keywords compared to BASE and BNC. The result indicates that there are specific linguistic choices or realisations used as they respond to other communicative purposes associated to this specific genre. Third, in the deployment of personal pronouns representing stance and engagement, the hard science presenters not only tended to use the personal pronouns to claim their authorial stance and engage their audience in the talks, but also to direct the audience's attention to the significance of the research conducted.

However, the result also shows that instead of relying on using explicit reader pronouns like you, your, or reader, speakers in the present research tend to engage their audience implicitly while projecting themselves by using the first person plural pronouns. In academic appendant genres, demonstrating how significant their host genre is may be understandable, but it is argued that perhaps speakers could also try to include the audience more explicitly and frequently to create a close connection and mutual rapport as business commercials do if the purpose of the text is to promote a product, either a commercial or academic one.

In addition, the present research has the following significance. First, regarding knowledge, compared to the extensive investigations of interactive language, stance and engagement in written texts, this study focuses on analysing spoken genres in an academic and promotional setting, which is relatively underrepresented in the literature.

Second, due to the development and convenience of technology platforms, the appendant genres embedded with promotional and evaluative purposes, such as highlights, bio-data, video-abstracts and audioslides, are exhibiting their growing importance in the competitive academic arena, and are gradually becoming required by world-leading journals. Researchers are now not only expected to publish their papers but also to promote their research to expand visibility and increase readership. The identification of the keywords in the present study can help authors produce a more attractive and scholastic presentation for their potential audience, thus motivating them to read the full 
text. In addition, the proper deployment of linguistic devices, that is, the personal pronouns to represent authorial position and engage readers, helps researchers not only make a persuasive proposition but also show academic solidarity with research communities.

Finally, the study also has some pedagogical significance for teaching novice scholars how to design audioslides and make a successful academic audioslide presentation. The results of the study present language teachers and university students, in particular postgraduate students, with the keywords and personal pronouns of an academic speech to persuade the audience and promote research, which would greatly help novice scholars learn how to deliver an effective speech in public and also digitally.

However, since the present research could be the first to explore this new academic spoken genre, several future studies can be carried out to complement it. First, a qualitative design can be integrated in future studies, where researchers can be surveyed about what they decide to report about their research in a very short talk, and how the specific lexis will be used to promote the research. Besides, future research can expand its scope to include audioslides from other disciplines, in particular the soft science domain, to display a more holistic picture of how this novel genre is properly accommodated in the competitive academic environment. In addition, including the talks from both knowledge domains can help identify an established generic structure of audioslide presentations, how this appendant genre is different from its host genres, that is research papers, how the audio relates to the visuals and what the significance of the balance of text and visuals is in the slides. Lastly, other similar appendant genres embedded with promotional purposes in academic publication can be cross-examined and compared to see whether there are similarities or differences in terms of the deployment of lexis and interactive language.

[Paper submitted 30 Nov 2016]

[Revised version received 2 Apr 2017]

[Revised version accepted for publication 21 May 2017]

\section{References}

Breivega, K., Dahl, T., \& Fløttum, K. (2002). Traces of self and others in research articles: A comparative pilot study of English, French and Norwegian research articles in medicine, economics and linguistics. International Journal of Applied Linguistics, 12(2), 218-233.

Bondi, M., \& Scott, M. (Eds.) (2010). Keyness in texts. Amsterdam: John Benjamins.

Carter-Thomas, S., \& Rowley-Jolivet, E. (2003). Analysing the scientific conference presentation (CP): A methodological overview of a multimodal genre. ASp. la revue du GERAS, 39-40, 59-72. 
Culpeper, J. (2009). Keyness: Words, parts-of-speech and semantic categories in the character-talk of Shakespeare's Romeo and Juliet. International Journal of Corpus Linguistics, 14(1), 29-59.

Elsevier. (2013). Audioslides competition winner announced. Retrieved from http://www.materialstoday.com/energy/news/audioslides-competition-winnerannounced/

Elsevier. (2014). Get noticed: Promoting your article to a maximum impact. Retrieved from http://www.elsevier.com/_data/assets/pdf_file/0011/218981/ELS-14-020Brochure-Get-Noticed-web-LR-single-pages.pdf?sf4897698=1

Elsevier. (2016). About the audioslides. Retrieved from https://www.elsevier.com/booksand-journals/content-innovation/audioslides

Fairclough, N. (1993). Critical discourse analysis and the marketisation of public discourse: The universities. Discourse \& Society, 4(2), 133-168.

Gluckman, T. (2014). How to win attraction for your research - An author's story. Retrieved from http://www.elsevier.com/authors-update/story/publishingtips/how-to-win-attention-for-your-research-an-authors-story

Groom, N. (2009). Phraseology and epistemology in academic book reviews: A corpusdriven analysis of two humanities disciplines. In K. Hyland, \& G. Diani (Eds.), Academic evaluation: Review genres in university settings (pp. 122-139). London: Palgrave Macmillan.

Hu, G., \& Cao, F. (2011). Hedging and boosting in abstracts of applied linguistics articles: A comparative study of English- and Chinese-medium journals. Journal of pragmatics, 43(11), 2795-2809.

Hyland, K. (2001). Bringing in the reader: Addressee features in academic writing. Written Communication, 18(4), 549-574.

Hyland, K. (2005a). Stance and engagement: A model of interaction in academic discourse. Discourse Studies, 7(2), 173-192.

Hyland, K. (2005b). Representing readers in writing: Students and expert writing. Linguistics and Education, 16(4), 363-377.

Hyland, K. (2008a). Disciplinary voices: Interaction in research writing. English Text Construction, 1, 5-22.

Hyland, K. (2008b). Persuasion, interaction, and the construction of knowledge: Representing self and others in research writing. International Journal of English Studies, 8(2), 1-23.

Hyland, K. (2012). Disciplinary identities: Individuality and community in academic discourse. Cambridge, England: Cambridge University Press.

Martin, J. R., \& White, P. (2005). The language of evaluation: Appraisal in English. Basingstoke, England: Palgrave Macmillan.

Mauranen, A. (1993). Cultural differences in academic rhetoric: A textlinguistic study. Frankfurt: Peter Lang.

McGrath, L., \& Kuteeva, M. (2012). Stance and engagement in pure mathematics research articles: Linking discourse features to disciplinary practices. English for Specific Purposes, 31(3), 161-173.

Mur-Dueñas, P. (2007). 'I/we focus on.': A cross-cultural analysis of self-mentions in business management research articles. Journal of English for Academic Purposes, $6(2), 143-162$. 
North, S. (2005). Disciplinary variation in the use of theme in undergraduate essays. Applied Linguistics, 26, 431-452.

Okamura, A., \& Shaw, P. (2014). Development of academic journal abstracts in relation to the demands of stakeholders. In M. Bondi, \& R. Lorés Sanz (Eds.), Abstracts in academic discourse: Variation and change (pp. 287-318). Bern: Peter Lang.

Rowley-Jolivet, E., \& Carter-Thomas, S. (2005). The rhetoric of conference presentation introductions: Context, argument and interaction. International Journal of Applied Linguistics, 15(1), 45-71.

Schwanen, T., \& Kwan, M. P. (2008). The Internet, mobile phone and space-time constraints. Geoforum, 39(3), 1362-1377.

Scott, M. (2008). WordSmith tools (Version 3.0) [Computer software]. Liverpool, UK: Lexical Analysis Software.

Scott, M. (2014). Research using WordSmith tools. Retrieved from http://www.lexically.net/wordsmith/corpus_linguistics_links/papers_using_words mith.htm

Scott, M., \& Tribble, C. (2006). Textual patterns: Key words and corpus analysis in language education (Vol. 22). Amsterdam/Philadelphia: John Benjamins Publishing.

Sellgate. (2015). Audioslides. Retrieved from http://www.sellgate.ag/en/salestools/audio-slides/

Shaw, P., Kuteeva, M., \& Okamura, A. (2014). Submission letters for academic publication: Disciplinary differences and promotional language. Journal of English for Academic Purposes, 14, 106-117.

Shaw, P. (2016). Genre analysis. In K. Hyland, \& P. Shaw (Eds.), The Routledge handbook of English for academic purposes (pp. 243-255). New York: Routledge.

Tribble, C. (2013). Corpora and corpus analysis: New windows on academic writing. In J. Flowerdew (Ed.), Academic discourse (pp. 131-149). Oxon: Routledge.

Tse, P. (2012). Stance in academic bios. In K. Hyland, \& C. Sancho Guinda (Eds.), Stance and voice in written academic genres (pp. 69-84). Basingstoke: Palgrave Macmillan.

Yang, W. H. (2012). A genre analysis of PhD dissertation acknowledgements across disciplinary variations. LSP Journal, 3(2), 51-70.

Yang, W. H. (2013). Two-folded messages behind CFP: A cross disciplinary examination. International Journal of Language Studies, 7(2), 83-108.

Yang, W. H. (2014). Stance and engagement: A corpus-based analysis of academic spoken discourse across science domains. LSP Journal, 5(1), 62-78.

Yang, W. H. (2015). "Call for papers": Analysis of the schematic structure and lexicogrammar in CFPs for academic conferences. English for Specific Purposes, 37, 39-51.

Yang, W. H. (2016). Evaluative language and interactive discourse in journal article highlights. English for Specific Purposes, 42, 89-103.

WENHSIEN YANG is Associate Professor in the Department of Applied English at National Kaohsiung University of Hospitality and Tourism, Taiwan. His main research and teaching interests include the areas of ESP, genre analysis, corpus linguistics, second language writing and CLIL (content and language integrated learning). 


\section{Appendix}

\section{Frequency and common collocations of the personal pronouns}

\begin{tabular}{|c|c|c|}
\hline Pronoun & FrEQUENCY & Collocation \\
\hline$I$ & 134 & $\begin{array}{l}\text { I will... (14), I am... (12), I'm... (6), As I... (3), ...minutes, I...(7), Hello, I... } \\
\text { (3) }\end{array}$ \\
\hline$W e$ & 302 & $\begin{array}{l}\text { we can...(35), we have...(30), we use...(19), we are...(8), we also...(7), we } \\
\text { need...(7), we propose... (7), we find...(5), we used...(6), we would...(5), } \\
\text { we will...(4), we present...(4), we show...(4), we compare...(5), Then, } \\
\text { we...(4), Do we...(3), what we...(4), the way we...(4), if we...(5),...study } \\
\text { we...(4),...result we...(4) }\end{array}$ \\
\hline Our & 84 & $\begin{array}{l}\text { our paper...(4), our research...(6), our approach...(4), our work...(3), our } \\
\text { method...(5), our proposed...(4), } \\
\text { in our...(10), of our...(8) That our...(5), } \\
\text { for our...(12), ...summarise our...(2) }\end{array}$ \\
\hline$U S$ & 23 & allow us...(8) \\
\hline You & 79 & $\begin{array}{l}\text { thank you for...(13), thank you (13), you can...(16), you know...(3), That } \\
\text { you...(5), hope you...(3), as you...(5) }\end{array}$ \\
\hline Your & 21 & for your...(13), to your...(2) \\
\hline Reader & 1 & reader can... (1) \\
\hline
\end{tabular}

NOTE: The number in brackets indicates the frequency. 